19 Wold B, Torsheim T, Currie C, Roberts C: National and school policies on restrictions of teacher smoking: a multilevel analysis of student exposure to teacher smoking in seven European countries. Health Educ Res 2004;19:217-226.

20 Charlton A, While D: Smoking prevalence among 16-19 year-olds related to smoking policies in sixth forms and further education. Health Educ J 1994;53:28-39.

21 Maes L, Lievens J: Can the school make a difference? A multilevel analysis of adolescent risk and health behaviour. Soc Sci Med 2003 . 56:517-529.
22 Rosendahl KI, Galanti MR, Gilljam H, Bremberg S, Ahlbom A: School and class environments are differently linked to future smoking among preadolescents. Prev Med 2002; 34:649-654.

23 Kannas L, Schmidt B: Policy Implications and Recommendations for a Smoke-Free School (International Study: Control of Adolescent Smoking). Helsinki, European Network on Young People and Tobacco, 2001.

24 Aveyard P, Markham W, Cheng K: A methodological and substantive review of the evidence that schools cause pupils to smoke. Soc Sci Med 2004;58:2253-2265.

25 Dolcini MM, Adler NE, Ginsberg D: Factors influencing agreement between self-reports and biological measures of smoking among adolescents. J Res Adolesc 1996;6:515-542.
26 Evans-Whipp T, Beyers JM, Lloyd S, Lafazia AN, Toumbourou JW, Arthur MW, et al: A review of school drug policies and their impact on youth substance use. Health Promot Int 2004;19:227-234.

27 Engels RCME, Vitaro F, Blokland ED, de Kemp R, Scholte RHJ: Influence and selection processes in friendships and adolescent smoking behaviour: the role of parental smoking. J Adolesc 2004;27:531-544.

28 Bush T, Curry SJ, Hollis J, Grothaus L, Ludman E, McAfee T, et al: Preteen attitudes about smoking and parental factors associated with favorable attitudes. Am J Health Promot 2005; 19:410-417.

\title{
Announcement
}

\section{Jellinek Memorial Fund}

The Board of Directors of the Jellinek Memorial Fund is pleased to announce that the Jellinek Memorial Award for 2007 has been awarded to Dr. Bridget F. Grant (Laboratory of Epidemiology and Biometry, Division of Intramural Clinical and Biological Research, NIAAA, National Institute of Health, Bethesda, Md., USA) for outstanding leadership in the design, implementation and analysis of major epidemiologic surveys in the field of alcohol and drug use disorders and psychiatric comorbidities. The award was presented by Dr. Boris Tabakoff at the RSA Annual Meeting in Chicago, Ill., on July 11, 2007. The Jellinek Award consists of CAD 5,000 together with a bust of the late E.M. Jellinek.

The Board of the Jellinek Memorial Fund also wishes to announce that the Selection Committee for the 2009 award is chaired by Dr. Thomas Babor. The specific category is 'Social, Cultural and Policy Studies'. Nominations for this award can be forwarded until October 1, 2008 to:

Dr. Thomas Babor

Department of Community Medicine

University of Connecticut School of Medicine

263 Farmington Avenue

Farmington, CT 06030-6325 (USA)

Nominations may also be submitted online at www.jellinekaward.org. 